\title{
A Identificação de Doentes com Necessidades Paliativas nas Enfermarias de Medicina Interna: Colocar os Doentes Vulneráveis no Centro dos Cuidados

\author{
The Identification of Patients with Palliative Needs in Internal Medicine \\ Wards: Placing Vulnerable Patients at the Center of Care
}

\author{
Hugo Jorge Casimiro ${ }^{1-3}$ (https://orcid.org/0000-0002-8867-3159), Paulo Reis-Pina ${ }^{4-6}$ (https://orcid.org/0000-0002- \\ 4665-585X)
}

Palavras-chave: Cuidados Paliativos; Cuidados Terminais; Encaminhamento e Consulta; Medicina Interna; Prestação Integrada de Cuidados de Saúde.

Keywords: Delivery of Health Care, Integrated; Internal Medicine; Palliative Care; Referral and Consultation; Terminal Care.

Recently, Martins presented the results of the application of the Palliative Care Screening Tool (PCST) regarding a group of patients admitted to an Internal Medicine ward over a three-month period, identifying and characterizing those with palliative needs (PN). ${ }^{1}$ Although many individuals with chronic diseases, in advanced stages, need palliative care $(P C)$, there are difficulties as far as the effective access to this type of specialized follow-up is concerned. Two common misconceptions regarding PC are: i) its preferential indication for cancer patients; ii) the late referral of individuals, mainly at the terminal phase of their lives. It is notoriously harder to acknowledge PN in patients with non-cancer pathologies, culminating in limited access of these to PC of excellence. ${ }^{2}$ However, even in cancer patients there is a clear clinical delay respecting early referral to $\mathrm{PC} .{ }^{3}$ To better train health professionals there are instruments allowing the early identification of patients with PN and assisting in the PC planning. Examples are: the "Gold Standards Framework Proactive Identification Guidance" (GSF-PIG); the "RADboud indicators for PAlliative Care Needs" (RADPAC); the "Supportive \& Palliative Care Indicators Tool" (SPICT); and the

\footnotetext{
${ }^{1}$ Hospital Palliative Care Team, Setúbal Hospital Centre, Setúbal, Portugal.

2Internal Medicine Department, Setúbal Hospital Centre, Setúbal, Portugal.

Institute of Histology and Developmental Biology, Faculty of Medicine, University of Lisbon, Lisboa, Portugal.

"Palliative Care Unit "Bento Menni”, Casa de Saúde da Idanha, Sintra, Portugal.

${ }^{5}$ School of Medicine, University of Minho, Braga, Portugal.

${ }^{6}$ Faculty of Medicine, University of Lisbon, Lisboa, Portugal.

DOI:10.24950/CE/181/20/4/2020
}

"Necesidades Paliativas" (NECPAL), some of them already translated and validated in Portugal, particularly the last two instruments. Such tools allow the identification of a larger number of patients as they include mortality predictors (such as functional status and quality of life) and specific indicators related to the disease per se. ${ }^{2}$ By making exclusive use of the health professional's perception of the patient's PN, and by not including those predictors and indicators, there may be up to two thirds of cases where the need for PC is not recognized. ${ }^{2}$ Using the PCST, a simple and easy scale, Martins showed that PN existed in 54\% of the hospitalized patients. ${ }^{1}$ Its application in a Brazilian Geriatric and Convalescent Hospital identified $86 \%$ of patients with $\mathrm{PN} .{ }^{4} \mathrm{Al}-$ though there may be differences in the population of both studies contributing to the disparity of results, these figures may also suggest the need for an adequate translation, cultural adaptation, and validation of these instruments. It should be said that Martins' version did not undergo a process of cross-cultural validation in Portugal. In addition to the identification of patients with $\mathrm{PN}$, it is also important to understand the extent to which this knowledge may change healthcare professionals' attitudes towards care in hospital settings. Several studies in the field of General Practice have shown that teaching early identification of patients with $\mathrm{PN}$ leads to changes in the follow-up plan of these patients, with repercussions on the number of hospitalizations (towards a reduction) and the place of death (according to the patient's preferable choice). ${ }^{5}$ The identification of patients with PN is crucial for a greater availability of PC to the general population. Nonetheless, it will be part of a longer process, which should include a comprehensive training schedule to provide clear benefits to a larger number of patients. The negative connotation that the term "palliative" implies, together with the lack of clinical expertise in health communication and the fear of conveying a poor prognosis, can lead healthcare professionals to procrastinate this type of care. ${ }^{3}$ In Internal Medicine, while training residents, it is pertinent to have a mandatory internship in Palliative Medicine. Only by providing such will hospitals become centers of humanization where clinical relationships stand out, centripetal to the 
CARTAS AO EDITOR

vulnerable human person, where "curative" and "palliative" will not be mutually exclusive, but complementary parts of an integrated continuum of care.

\section{Responsabilidades Éticas}

Conflitos de Interesse: Os autores declaram a inexistência de conflitos de interesse na realização do presente trabalho.

Fontes de Financiamento: Não existiram fontes externas de financiamento para a realização deste artigo.

Proveniência e Revisão por Pares: Não comissionado; revisão externa por pares.

\section{Ethical Disclosures}

Conflicts of interest: The authors have no conflicts of interest to declare. Financing Support: This work has not received any contribution, grant or scholarship.

Provenance and Peer Review: Not commissioned; externally peer reviewed.

(C) Autor (es) (ou seu (s) empregador (es)) e Revista SPMI 2020. Reutilização permitida de acordo com CC BY-NC. Nenhuma reutilização comercial. (C) Author(s) (or their employer(s)) and SPMI Journal 2020. Re-use permitted under CC BY-NC. No commercial re-use.

\section{Correspondence / Correspondência:}

Hugo Jorge Casimiro - hugojorgecasimiro@gmail.com

Hospital Palliative Care Team, Setúbal Hospital Centre, Setúbal, Portugal

Rua Camilo Castelo Branco, Apartado 140 - 2910-446 Setúbal

Received / Recebido: 04/09/2020

Accepted / Aceite: 04/04/2020

Publicado / Published: 18 de Dezembro de 2020

\section{REFERENCES}

1. Martins O. Identificação de doentes internados num serviço de medicina interna com necessidade de cuidados paliativos. Rev Soc Port Med Interna. 2020;27:131-8. doi: 10.24950/O/265/19/2/2020

2. Martín-Lesende I, Recalde E, Viviane-Wunderling P, Pinar T, Borghesi F, Aguirre T, et al. Mortality in a cohort of complex patients with chronic illnesses and multimorbidity: a descriptive longitudinal study. BMC Palliat Care. 2016;15:42. doi: 10.1186/s12904-016-0111-x.

3. Santos RG, Reis-Pina P. Early referral to palliative care: the rationing of timely health care for cancer patients. Acta Med Port. 2019;32:475-6. doi: 10.20344/amp.11911.

4. Lucchetti G, Badan Neto AM, Ramos SAC, Faria LFC, Granero AL, Pires SL, et al. Use of a palliative care screening tool in elderly from a nursing home. Geriatr Gerontol Aging. 2009;3:104-8.

5. Thoonsen B, Groot M, Verhagen S, van Weel C, Vissers K, Engels Y. Timely identification of palliative patients and anticipatory care planning by GPS: practical application of tools and a training programme. BMC Palliat Care. 2016;15:39. doi:10.1186/s12904-016-0112-9 